IOWA 'TERRITORY AND GENERAI, JACKSON'S FINE

\author{
By David C. Moter
}

Pionecrs of Iowa were as much, or more, acquainted with national affairs as are our citizens today. In 1843 the whole country was discussing whether the fine imposed on General Andrew Jackson at New Orleans in 1815 should be remitted. Files of newspapers in this department, and proceedings of our Territorial Assembly, show the people here had decided opinions on the subject.

The facts are these: On the approach of the British fleet, or on December 16, 1814, General Jackson placed New Orleans and the adjacent region under martial law. The population of mixed Spanish, French, and Crcole, none too friendly to United States government, somewhat irked under Jackson's order. The famous battle occurred January 8, 1815. For some time thereafter the British continued to receive re-enforcements of soldiers embarked from England before the treaty of peace at Ghent was signed. By January 27 the British near New Orleans had embarked in their ships and soon thereafter the fleet sailed around to Mobile Bay and attacked and captured Fort Bowyer in that harbor. Rumors that peace had been agreed upon had reached New Orleans, but Jackson's sleepless vigilance and caution would not permit him to slacken the restraints of martial law. A few small politicians led the agitation to restore civil government. By February 18 news of the signing of the treaty reached New Orleans, but Jackson's sleepless vigilance and cauadvices had reached General Jackson, who besought patience of the people until the good news should come through our own government. On February 21 the Louisiana Gasette published a paragraph stating that "a flag has just arrived from Admiral Cochrane to General Jackson officially announcing the conclusion of peace at Ghent between the United States and Great Britain, and virtually requesting a suspension of arms." General Jackson at once sent a communication to the editor denouncing the statement as untruc, and requiring publication of a correction, which was made. But in the Gazelte of March 3 an 
article appeared in French making an appeal to the French of the city and state to resist the authority of the American general. The tone was moderate and complimentary to General Jackson, but he summoned the editor to headquarters, and demanded the name of the author. The editor said it was M. Iouaillier, a member of the legislature. Two days later Louaillier was arrested by the provost guard and placed in confinement in the officers' quarters of the barracks. Pierre Louis Morel, a French lawyer, as counsel for Louaillier, at once went before Judge D. A. Hall, United States judge of the District Court of Lonisiana, and obtained a writ of habeas corpus, which was served on General Jackson the same day. General Jackson then issued the following order: "Having received proof that Dominick A. Hall has been aiding and abetting and exciting mutiny within my camp, you will forthwith order a detachment to arrest and confine him and report to me as soon as arrested. (Signed) $A$. Jackson, Maj. Gen. Commanding." Judge Hall was arrested and confined in the barracks along with Louaillier. The latter was placed on trial by court martial, but only arraigned. Judge Hall was sent beyond the lines of sentinels with orders to stay outside "until the ratification of peace shall be regularly announced, or until the British forces shall have left the southern coast."

On March 13 General Jackson received dispatches from Washington announcing the ratification of the treaty by the Senate, and within an hour thereafter a general order was posted through all the public places abrogating martial law, restoring civil authority, and granting immunity for all military offenses. The volunteers returned home. General Jackson, with a small detachment of regular troops, remained. He was busy, among other things, settling claims of citizens whose supplies had been taken or seized under martial law. On March 24 Judge Hall, who had resumed his duties on the bench, issued a bench warrant for the apprehension of Andrew Jackson, charging him with contempt of court. The General promptly appeared with his counsel, Edward Livingston. The latter was allowed to proceed but a short time in presenting the defense when the judge interrupted, summarily adjudged General Jackson to be in contempt, and fined him a thousand dollars, to be paid on or before March 
31. As the General left the court room the people seized him, raised lim upon their shoulders, bore him into the street, denounced Judge Hall, and created disorder. 'The General quieted them, asked them to observe the peace, repaired to his headquarters and sent the court by an orderly his check for the amount of the fine. (See "History of Andrew Jackson," by $\Lambda$. C. Bell, Vol. II, pp. 50-90.)

This closed the episode for the time, or until his presidential campaigns, when it was revived to some extent by the Whigs, but without much effect. After General Jackson retired from the presidency in 1837, he became financially embarrassed, and was accommodated by loans 'from his friends. When this became known to others a bill was introduced in Congress March 10, 1842 , by Senator Linn of Missouri to remit the fine of $\$ 1,000 \mathrm{im}$ posed by Judge Hall. This aroused much discussion over the country and bitter opposition from the Whigs. In Iowa the Bloomington (afterward Muscatine) Herald (Democratic) of August 8, 18\%2, noted with favor the introduction in Congress of the bill to refund the fine, and in its edition of $A_{\text {pril }}$ 15 gave at length a statement rehcarsing the facts and justifying the General. The Lee County Democrat (Democratic) of Fort Madison in its edition of June 25, 1842, editorially denounced the Whig House of Congress for providing to refund the fine, but approving the course of Judge Hall in imposing it. It published a letter of General Jackson on the subject.

The Fifth Territorial Assembly of Iowa met at Iowa City December 6, 1842, during the height of this controversy. The legislatures of several states had already passed resolutions petitioning Congress to reimburse General Jackson, and the Democrats of the assembly of Iowa Territory evidently were of a mind that they should do the same. On February 10, 184:3, Thomas Rogers of Dubuque County introduced "H. R. F. No. 120 , a joint resolution relative to the repayment of the fine imposed upon General Jackson, which was read a first time." The next day it was read a second time and on motion of Thomas McMillan of Henry County it was "committed to the Committee of the Whole and made the order of the day for "Tuesday." Iebruary 15 it was considered in Committee of the Whole, Henry Felkner of Johnson County in the rhair, and after some time 
the committee rose and reported it back to the House with an amendment, which was agreed to. George $\mathbf{H}$. Walworth of the Cedar-Linn-Jones District "moved to amend by inserting the following after the third resolution of the same: Provided that nothing contained in these resolutions shall be so construed as to reflect any disrespect upon the conduct and decision of Judge Hall, in imposing said fine." Mr. Lewis of Van Buren County moved to adjourn, which motion was lost. The question was then taken upon the adoption of the proviso, by yeas and nays.

Those who voted in the affirmative were David E. Blair, Des Moines Co.; David Bunker, Washington Co.; Evan Jay, Henry Co.; Isaac N. Lewis, Van Buren Co.; Thomas McMillan, Henry Co.; Joseph Newell, Louisa Co.; Joseph M. Robertson, Scott Co.; David J. Sales, Des Moines Co.; William Steele, Lee Co.; Err Thornton, Muscatine Co.; George H. Wolworth, Cedar-LimnJones Dist.; Paton Wilson, Henry Co., 12, all of whom were Whigs.

Those who voted in the negative were Frederick Andros, Dubuque Co.; Rickey D. Barton, Van Buren Co.; John C. Berry, Limn Co.; James Bricrly, Lee Co.; Ansel Briggs, Jackson Co.; John W. Culbertson, Jefferson Co.; Henry Felkner, Jolmson Co.; Eli Goddard, Clinton Co.; Abner Hacklcman, Des Moines Co.; George Hepner, Des Moines Co.; N. S. MeCullock, Ice Co.; Thomas Rogers, Dubuque Co.; Samuel Swearengen, Van Buren Co.; Speaker, James M. Morgan, Des Moines Co., 14, all of whom were Democrats. So the motion was lost.

Mr. Walworth "moved to amend the third resolution by inserting the following: Provided, that the provisions of this resolution slaall not be so construed as to express any opinion in relation to the conduct or decision of Judge Hall in imposing said fine," upon which the yeas and nays were ordered.

Those who voted in the affirmative were Blair, Bunker, Jay, Lewis, McMillian, Newell, Robertson, Sales, Steele, Thornton, Walworth, Wilson.-12.

Those who voted in the negative were Andros, Barton, Berry, Brierly, Briggs, Culbertson, Felkner, Goddard, Hackleman, Hepner, McCulloch, Rogers, Swearingen, Speaker.-14. So the motion was lost.

Payton Wilson of Henry County moved to adjoụn, which motion was lost. 
Mr. Rogers "moved to suspend the forty-second rule [which prohibited the second and third reading to be made on the same day without special order of the house] and that the joint resolution be read a third time now," upon which the yeas and nays were ordered, yeas 17 , nays 9.

Those who voted in the affirmative were Andros, Barton, Berry, Brierly, Briggs, Culbertson, Felkner, Goddard, Hackleman, Hepner, Lewis, McCulloch, Robertson, Rogers, Steele, Swearingen, Speaker. -17 .

Those who voted in the affirmative were Andros, Barton, Berry, McMillan, Newell, Sales, 'Thornton, Walworth, Wilson.-9. So the motion was lost for want of a two-thirds majority.

David J. Sales of Des Moines County moved to adjourn, which motion was lost.

Mr. Rogers "moved that the resolution be engrossed and read a third time tomorrow," upon which motion the yeas and nays were ordered.

Those who voted in the affirmative were Andros, Barton, Berry, Brierly, Briggs, Culbertson, Felkner, Goddard, Hackleman, Hepner, Lewis, McCullock, Rogers, Swearingen, Walworth, Speaker. -16 .

'Those who voted in the negative were, Jlair, Bunker, Jay, McMillan, Newell, Robertson, Sales, Stecle, Thornton, Wilson.-10. So the motion was agreed to.

On February 16 Rickey D. Barton of Van Buren County from the committee on engrossed bills reported they examined $\mathbf{H}$. R. F. No. 120, joint resolution relative to the repayment of the fine imposed on General Jackson and found the same to be correctly cngrossed.

The resolution was then read a third time. Frederick Andros of Dubuque County moved to amend the same by adding the following: "Resolved, that we believe the fine imposed by Judge Hall ca: General Jackson was uncalled for by the circumstances of the case, and was an act of injustice to the veteran hero, savoring of the spirit of vindictiveness and jealousy." Mr. Andros asked leave to withdraw the same, upon which the yeas and nays were called.

Those who voted in the affirmative were Andros, Barton, Berry, Brierly, Briggs, Culbertson, Felkner, Goddard, Hackleman, Hepner, Steele, Swearingen, Thornton, Speaker.-18. 
Those who voted in the negative were, Blair, Bunker, Jay, McMillan, Sales.-5. So leave was granted.

Isaac N. Lewis of Van Buren County moved to amend by adding the following to the same: "Resolved further that the present legislative assembly pay General Jackson back the fine imposed on him by Judge Hall and that each member of this legislature pay his proportional part to the chief clerk of this House for this purpose."

Abner Hackleman of Des Moines County moved to amend the amendment by inserting the following thereto: "Provided the gentleman from Van Buren County be employed to carry the same to General Jackson and deliver the same without any compensation," which motion was lost.

The question was then taken on the original amendment, the yeas and nays were ordered; yeas 1, nays 22, Mr. Lewis being the only one voting in the affirmative.

The question was then taken upon the passage of the resolution by yeas and nays.

Those who voted in the affirmative were, Andros, Barton, Berry, Blair, Brierly, Briggs, Culbertson, Felkner, Goddard; Hackleman, Hepner, Lewis, McCulloch, Rogers, Sales, Stcele, Swearingen, Tliornton, Speaker.-19.

Those who voted in the negative were, Bunker, Jay, McMillan, Robertson.-4. So the motion was agreed to and the same read a third time, passed and the title agreed to.

During the afternoon session of the Council of the same day, February 16, being the last day but one of that session, the resolution was messaged over from the House as having passed that body. Dr. John D. Elbert of Van Buren County, president of the Council, seems to have vacated the chair for the purpose of taking part in the proceedings. The following record appears in the journal of the Council at that time: "On motion of Mr. Elbert, ordered that No. 120, H. R. F., Joint Resolution relative to the repayment of the fine imposed upon General Jackson, be taken from the table. On motion of Mr. Elbert, ordered, that the 'Thirteenth Rule [which prohibited the second and third reading to be made on the same day without spectal order of the Council] be suspended and said resolution be read a third time now. The resolution was then read a third time. On motion of Mr. Elbert, 
ordered, that said resolution do lie upon the table." The reasons for the Council, which stood seven Democrats to six Whigs, tabling the resolution without even a roll call, and not again calling it up, are not revealed.

Just one year to a day after this final episode in the Iowa Territorial Assembly, or on February 16, 1844, Congress passed the act, which was approved, remitting the fine to General Jackson, which, with the interest, then amounted to $\$ 2,732$. 'Then, a little over a year later, or on June 8,1845 , the heroic old warrior and statesman peacefully passed to rest.

\section{PRIN'TERS' FESTIVAI,}

The cditors, ex-editors, and printers assembled at 1) Moins to the number of seventy, had a good time generally at the Collin's House last evening at the Printers' Festival. The asscmblage embraced several gentlemen who have figured conspicuously in the editorial arena. We have only time and room to say that the lost of the Collin's House did himself honor by the feast of good things prepared for the occasion.-The Iotea Citi$z e n$, Des Moines, January 19, 1858. (In the newspajer collection of the Historical, Memorial and Art Department of Iowa.)

\section{GREELIY'S ALMANAC}

This indispensable political calendar for 1858 has been placed on our table, through the politeness of the publishers. Contents, as usual, exceedingly valuable for reference to all who are interested in the political history of the country. The election returns of the past year, members of Congress, laws of late Congress, naticnal platforms, \&c., are among the contents; with historic sketches of events in Kansas, \&c.-The Iozea Citisen, Des Moines, January 30, 1858 . (In the newspaper collection of the Historical, Memorial and Art Department of Iowa.) 
Copyright of Annals of Iowa is the property of State of Iowa, by \& through the State Historical Society of Iowa and its content may not be copied or emailed to multiple sites or posted to a listserv without the copyright holder's express written permission. However, users may print, download, or email articles for individual use. 